\title{
ARTICLES
}

MARIUSZ BARANOWSKI*

Adam Mickiewicz University in Poznań

DOI: $10.26485 / \mathrm{PS} / 2017 / 66.4 / 1$

\section{WELFARE SOCIOLOGY IN OUR TIMES. HOW SOCIAL, POLITICAL, AND ECONOMIC UNCERTAINTIES SHAPE CONTEMPORARY SOCIETIES}

\begin{abstract}
This article attempts to present the welfare sociology approach to the problems and dilemmas of modern developed capitalist societies. In addition to describing areas of interest in welfare sociology, primarily welfare economics and positive psychology, the focus will be on the characteristics of the condition of modern societies. For this purpose, the term 'uncertainty', which is well suited for characterizing the various dimensions of post-modern societies, will be used. Nevertheless, one should keep in mind that this concept has not reached the creditable sociological elaboration (except for the work of economists on precarious forms of employment). As sociologically defined, welfare will be used for analyzing changes in the structure of social differentiation, as well as in social relationships, educational opportunities, political attitudes, patterns of consumption and leisure, to name a few. All these changes reflect not only the impact of globalization on social security systems, but also the consequences of the technological revolution and demographic challenges on subjectively perceived social welfare.
\end{abstract}

* Dr, Institute of Sociology; e-mail: mariusz.baranowski@amu.edu.pl 
Keywords: welfare sociology; capitalist society; uncertainty; social justice; precariat; antisocial institutional changes

\section{INTRODUCTION}

Welfare sociology does not constitute a separate sub-discipline of sociology, which is all the more surprising when we take a closer look at the concept of welfare itself (sometimes substituted by terms such as well-being, happiness, health, quality of life etc.), which, among other things, designates the normative goals that societies aim to achieve. The understanding of welfare can differ substantially between different societies, but they are nonetheless "created" in the practice of social life, with its cultural patterns, division of social labour and/ or the historical determinants of existing institutions. For example, taking for its object the study of need fulfilment from the perspective of economic processes, economics is also concerned with welfare, which is further explored by its subdiscipline called welfare economics. Psychology, undertaking a broad study of the foundations for and consequences of an individuals' actions, inadvertently ends up describing the subjective conditions for welfare (and the specifics of welfare and wellbeing - see: Taylor 2011: 777-794), particularly in the specialised field of positive psychology. In democratic countries the social sciences, apart from their main object of interest, which is power as an element of struggle for influence, explore a variety of other important social questions which have tangible emancipatory consequences for people who are in danger of institutional exclusion [cf. Marshall 2009; Renn 2008]. The common ground for the aforementioned fields where welfare can be studied, together with some which have not been mentioned (philosophy, cultural studies, law, and the field most commonly associated with the issue - social policy) should be sociology [cf. Gouldner 1968], as "sociological insights have served in a number of instances to improve the lot of groups of human beings by uncovering morally shocking conditions, clearing away collective illusions, or by showing that socially desired results could be obtained in more human fashion" [Berger 1963: 7]. In sociology, the focus has largely been placed on the diagnosis and attempts to solve burning social issues (sociology of social problems) associated with poverty, social exclusion, anomie, unemployment [Barbieri 2009], etc. Because of that, not enough attention has been paid to the issue of welfare - in particular its positive aspect. This does not mean building a one-sided vision of a society based on the issue of welfare, which has many years ago been labelled "lyrical sociology" (Jan Strzelecki, 
Kozyr-Kowalski) and which takes for its subject the beneficial aspects of social "development" and focuses on positive achievements. An interest in those areas which are avoided by researchers from other fields is a well-known trait of the sociological approach. Because these burning social problems and issues have been taken up, measurable results have been achieved in the form of advanced studies of these phenomena; studies which, when properly recognised and named, become easier to transform in the desirable way. The sociology of welfare, building on existing achievements and considering the interdisciplinary character of welfare itself, should be at the heart of studies of social reality, concerning both the material conditions and the psychological sphere (e.g. affluenza [de Graaf, Wann, Naylor 2005]).

\section{WELFARE AS A KEY CONCEPT}

Efforts made by social sciences, humanities (e.g. philosophy) or practical doctrines (e.g. law) are aimed at carefully considering the theoretical conditions and practical consequences of certain modes of human existence. Arete, a concept undertaken by ancient thinkers, for example in the context of combining goodness and beauty as marks of the ideal type of social upbringing (kalos kagathos), was by no means the first example of such considerations. Both the mental exertions and practical attempts at implementing a given social utopia had welfare at their foundations. This term could be understood in a variety of ways, sometimes as happiness, or justice, sometimes as quality of life [cf. Diener, Suh 1997].

In his book, "A Theory of Justice" [1999 (1971)], John Rawls proposed the broadly discussed concept of "justice as fairness", but he also pointed out the social determinants of any concept of justice. He wrote directly about "fundamental social problems, in particular those of coordination, efficiency, and stability" [1999: 5], which designate the conditions for attaining welfare understood as a common good. The last book by Guy Standing [2017], which discusses the basic income proposal, also very clearly refers to the rule of social justice as a reference point for judging the various elements of contemporary social policies. Some of the individual practices of social welfare are tested using component concepts of social justice, such as "the security difference principle, the paternalism test principle, the rights-not-charity principle", as well as "the ecological constraint principle and the dignified work principle" [2017].

Quality of life, which is an object of interest for many disciplines and subdisciplines of science, can be paraphrased, in Zygmunt Bauman's sociology, as the right to a good life [Bauman 2011]. This is not limited to the material means 
of life, ways of spending free time, type of work and relations with friends and family, but also includes the quality of the natural environment and civic engagement (political and quasi-political activity) [cf. Blackshaw 2016; Caruana 2007]. Consumption is not an unimportant phenomenon here, as it has been playing a major role in developed societies since the beginning of industrial capitalism [Baudrillard 1998 (1970)]. It not only influences the quality of life, but also the subjective feeling of happiness, which is perhaps best manifested by the relative income hypothesis by James S. Duesenberry, in which attention is called to the role of external effects in consumption, which have to do with interrelations between households. As a result, the fulfilment of needs is linked to the demonstration effect, because individual people compare their own consumption to the consumption level of their family, friends, and neighbours [cf. Veenhoven 2008]. This means that subjective welfare is created within a certain social context, defined by comparisons to the so-called significant others (which in turn contradicts the concept of homo oeconomicus).

Some thinkers claim that " $[\mathrm{t}]$ he starting-point for defining well-being in current debate is often followed by a departure from the overall happiness or life satisfaction in a population. This is a consequence of a shift of focus within psychology and sociology away from historical accounts of exploring well-being that primarily involved the study of illness and dysfunctionality" [Bengtsson 2015: 21].

Problems already appear on the level of linguistic specification of the term welfare, because some differentiate between "personal well-being and collective welfare" [Max-Neef 1995: 115], while others talk about "subjective well-being" and "social welfare, i.e., human happiness", or of "human welfare" [Ball, Chernova 2008: 500] or "individual welfare" [Graham, Felton 2005].

Manfred Max-Neef [1995: 117] proposed a "Threshold Hypothesis, stating that: for every society there seems to be a period in which economic growth (as conventionally measured) brings about an improvement in the quality of life, but only up to a point - the threshold point - beyond which, if there is more economic growth, the quality of life may begin to deteriorate". This hypothesis expresses the intuitions of how subjective well-being is connected to a more measurable notion of welfare in classic conceptualisations. This should be taken into consideration, as it is impossible to abstract oneself from individual mechanisms of assessing one's own life (which is also dependent on the quality of life of other individuals or broader social categories).

For example, a critique of economic studies of welfare "emphasized that income standards are useless in societies where non-monetary services and benefits to a very large degree contribute to the welfare of the individual. Social indicat- 
ing is inadequate because it is based on clearly visible and directly measurable phenomena only. It cannot examine inequalities and deprivation stemming from the division of welfare and unequal access to the distributional welfare systems. (...) Living conditions analysis should not exclusively measure monetary incomes of individuals and families, but also their resources, material as non-material. Resources were to be seen as products of social relations of distribution. This involved the studies of resource distribution not only resulting from the operation of the mechanisms of the market, but also of the family, the community, and the state" [Henriksen 1987: 384].

A similar observation was made by Amartya Sen, who in Development as Freedom [2000 (1999)] described differences in subjectively-assessed happiness and objective living conditions that can be observed between different countries. The form of economic 'unfreedom', often in the form of extreme poverty, has played an important role in his work, as "economic unfreedom can breed social unfreedom, just as social or political unfreedom can also foster economic unfreedom" [2000: 8].

On the other hand, disputing the economic approach (e.g. Amartya Sen's), Louis Kaplow and Steven Shavell [2001: 282] claimed that "(...) any conceivable notion of social welfare that does not depend solely on individuals' utilities will sometimes require adoption of a policy that makes every person worse off." And, more importantly, "the tension between concern for individuals' well-being and conceptions of social welfare that give weight to factors apart from their well-being is sharper than may have been apparent; endorsement of any form of non-welfarist policy assessment implies that, in certain circumstances, it is socially desirable to make everyone worse off" [2001: 282].

The above fragment conveys the complicated relations between individual well-being and social welfare, which, when analysed from a particular perspective, becomes difficult to reconcile. The phenomenon of affluenza is a perfect example, because - as Amartya Sen also pointed out - the individual perspective of valuation is influenced by many factors. This is why in some surveys people living in developed economies in relatively comfortable conditions have declared a lowlevel of life satisfaction (and also material conditions, despite having several cars and a large house). It's worth noting that differences between developed countries and those where income per capita is low are not simply relative, but also absolute: "African Americans [in the United States - M.B.] have an "absolutely" lower chance of reaching mature ages than do people of many third world societies, such as China, or Sri Lanka, or parts of India (with different arrangements of health care, education, and community relations)" [Sen 2000: 6]. 


\section{WHAT IS CERTAINLY CERTAIN IS UNCERTAINTY}

Uncertainty constitutes an inseparable part of human life in the contemporary world, including in the enclaves of economic development. However, the nature of uncertainty has changed [Beck 1992], and its influence on societies has increased significantly in recent decades. According to Robert Castel, author of La montée des incertitudes, between the end of WW2 and the early 1970s, the vast majority of French citizens looked at their futures with enthusiasm, despite the situation being far from ideal, containing "strong inequalities, massive injustice, pockets of poverty, institutional violence and merciless relations of domination" [Castel 2016: 160]. Today, the situation is significantly different, as pessimistic attitudes towards the future dominate, including among the French. According to a French sociologist, "we had entered into a new, more aggressive economic dynamic, which intensified competition at the global level under the hegemony of international finance capital. This new regime of capitalism caught off guard, weakened and sometimes destroyed forms of social organization that had been established at the end of industrial capitalism" [Castel 2016: 161].

In his most recent work [2017], the above-mentioned Guy Standing adopted a broad understanding of inequality, which is not limited to the economic aspect, but also refers to inequality of security and - most importantly - feelings of certainty. Jens Zinn from the University of Melbourne characterised the phenomenon of uncertainty and linked it to expectations in the following way:

"Uncertainty is characterized by cognitive and emotional elements. Uncertainty indicates unclear, ambiguous, or contradictory cognitive constructions, which cause feelings of uncertainty. In sociology as well as economics, uncertainty is about expectations. It refers to the future and whether our expectations will be met and also to the present and our capacity to produce expectations. Typically, norms and institutions structure our expectations. They support clear and unambiguous notions and expectations even though they are always - to a certain degree - uncertain" [Zinn 2007: 5097].

The problem is that these norms and institutions Zinn writes about are undergoing increasingly rapid transformations in contemporary societies, causing a decline in the feeling of "ontological security". Anthony Giddens used the term "manufactured uncertainty" (or "manufactured risk") in order to emphasise the changes happening at all the levels of organisation of contemporary societies. The term itself, according to the British sociologist, "comes from human involvement in trying to change the course of history or alter the contours of nature. We can separate manufactured risk from external risk. External risk refers to sources 
of uncertainty which come either from unmastered nature or from "unmastered history" - that is, history as lived by taken-for-granted traditions, customs and practices" [Giddens 1995: 2].

Uncertainty, though present on every level of societal development, becomes particularly visible during economic and social crises, because during such times the social changes happen at an increased pace and force existing institutions (understood after Douglass C. North very broadly as "the rules of the game in a society or, more formally, the humanly devised constraints that shape human interaction" [1990: 3]) to fall apart [Harvey 2014].

Alain Touraine [2014] made an important observation pertaining to the last economic crisis and differentiated between a crisis of a capitalist society and a crisis of capitalism itself, and underlined the weakness of the state and socialeconomic entities when faced with an offensive by large financial institutions and banks. Loïc Wacquant touches upon a similar subject in his works, pointing out that "castaway categories - unemployed youth left adrift, the beggars and the homeless, aimless nomads and drug addicts, postcolonial immigrants without documents or support - have become salient in public space, their presence undesirable and their doings intolerable, because they are the "living and threatening incarnation of the generalized social insecurity" produced by the erosion of stable and homogenous wage work (promoted to the rank of paradigm of employment during the decades of Fordist expansion in 1945-75) and by the decomposition of the solidarities of class and culture it underpinned within a clearly circumscribed national framework" [Wacquant 2009: 4]. This category was described by Immanuel Wallerstein [1999: 41] as "the dangerous classes", because "the point is that these populations have become volatile once again, and therefore dangerous once again from the point of view of the priviledged strata in the world-system" [1999: 45].

\section{AREAS OF UNCERTAINTY AND ANTISOCIAL SOCIAL POLICY}

August Comte, the father of sociology, wrote about the social dynamics' perspective, which became the foundation of sociology's contemporary approach to the challenges of social reality. This perspective draws our attention to the active and - using Bauman's term - "liquid" character of society. This means that social changes happen on multiple levels and are determined by such a high number of variables that it is difficult to control all of them, and thus to predict and actively modify them. From an individual's perspective, this causes a specific kind of uncertainty, because individual persons are not able to understand the 
piling up of changes (structural, technological, environmental). As an example, let us consider the challenges faced by Scandinavian countries, which have the most advanced welfare state institutions [see Table 1].

TABLE 1. Challenging the Nordic welfare model

\begin{tabular}{|l|c|l|}
\hline \multicolumn{1}{|c|}{$\begin{array}{c}\text { The Nordic welfare } \\
\text { model's core values: }\end{array}$} & \multicolumn{1}{c|}{ Evolving towards: } \\
\hline Universal coverage & $>$ & $\begin{array}{l}\text { Differentiation, individualization, need-based benefits, } \\
\text { earned entitlements }\end{array}$ \\
\hline Welfare based on citizenship & $>$ & Economic citizenship, customer choice \\
\hline Financing through taxation & $>$ & Insurance, partial payment \\
\hline Equal rights and status & $>$ & $\begin{array}{l}\text { Increased marginalization, social inheritance, economic } \\
\text { citizenship }\end{array}$ \\
\hline Equal opportunities and results & $>$ & $\begin{array}{l}\text { Increased marginalization, social inheritance, economic } \\
\text { citizenship }\end{array}$ \\
\hline $\begin{array}{l}\text { Dominant role played by the } \\
\text { state }\end{array}$ & $>$ & $\begin{array}{l}\text { Private, non-profit, voluntary sector, enterprises, civilian } \\
\text { society }\end{array}$ \\
\hline Decentralized services & $>$ & Services based on entitlements, national standards \\
\hline High-quality services & $>$ & $\begin{array}{l}\text { Uncertainty about what public welfare services will be } \\
\text { provided, saving up }\end{array}$ \\
\hline Generous benefits & $>$ & Welfare contracts, saving up \\
\hline High level of employment & $>$ & Yes, but many working-age people outside the workforce \\
\hline
\end{tabular}

Source: Morgen 2007: 12.

It can be clearly seen that the changes that are happening on many levels, further strengthening the feeling of uncertainty rather than alleviating it. The characteristic quality of these changes is their departure from the vision of social policy as a universal civil right, towards conditionality, understood in various ways. Aid for those persons socially excluded or threatened by exclusion is being reduced in a number of ways, and welfare state institutions no longer aim at preventing dysfunction (preventive function) and instead offer interventions to the weakest groups (responsive function). The feeling of uncertainty that is a consequence of, for example, changes in the labour market, leads either to precarious forms of employment or other, even more serious, social problems (unemployment, poverty). In both cases, the consequences (psychological and social) are difficult to overcome, and when we take into account the antisocial character of social policy - most of them seem almost impossible to extract oneself from. The core of antisocial policy, as I understand it and as it affects the growing social uncertainty, is in setting goals and tasks that do not benefit the society as a whole 
(e.g. through policies which differentiate individuals or certain social categories and discriminate against chosen, i.e. the weakest, parts of the society). This does not lead to collective behaviours which can bind a community or a society; but quite the opposite - it causes fracturing and sets people against one another. Let us take a look at an example of such antisocial changes within a welfare state, as pointed out by Susanne MacGregor:

"There is a general move away from the full employment goal towards activation policies - such as the use of unemployment benefits to ensure compulsory training or redeployment, combined with support for low-paid work. For example, in the United States there is TANF (transitional aid to needy families) and in the United Kingdom, child tax credits. These reforms are helping to create a layer of low-paid workers on the margins of the labour market, dependent for their living standards on the state benefits. A cultural shift accompanies these policies, with increased emphasis on personal responsibility (memorably encapsulated in the US Personal Responsibility and Work Opportunity Reconciliation Act 1996). Those included in the economy and society have to exercise responsibility to provide for themselves and their families. For the excluded, however, the policies are not so much neoliberal as neo-conservative or authoritarian, with more intervention by the state, and more intrusive policies and surveillance" [2005: 144].

There are many more examples of such antisocial solutions [Standing 2011, 2014; Baranowski 2017], which target sick or disabled people. It is important to bear in mind, however, that they all aggravate the feeling of uncertainty among those who need help and support the most (both individual and social). This does not mean that antisocial social policy means only the dismemberment of existing institutions, but it means, most importantly, a change in approach to major social issues and problems. Data from various countries does not necessarily indicate a decline in spending on social care (or social policy), but the form, assumptions and solutions that are employed can lead to stigmatization, humiliation, and increase the uncertainty of the subjects. This is what I mean by antisocial solutions that further separate those in most need from social welfare.

\section{WELFARE SOCIOLOGY AND THE CHALLENGES OF TODAY}

The proposal to employ the sociological perspective to look at welfare as broadly understood (i.e. encompassing both the subjective satisfaction/dissatisfaction with life and material conditions, as well as access to infrastructure and public institutions) is aimed to help create a perspective that would allow a deepened diagnosis of the contemporary determinants of this issue. The goal is to overcome 
the barriers between the "interests" of various scientific disciplines and practical doctrines in order to design multifaceted solutions aimed at ensuring the highest possible level of welfare. This is possible, on one hand, through the use of a number of "standard" (though not trivial) methods: partial reforms of existing welfare state institutions; limiting the income and wealth disparity; change of consumer attitudes etc. On the other hand, given the demographic challenges (ageing societies), imperfections of labour markets (with precarious forms of employment), technological changes (automation), psychological determinants of dynamic social change (mental disorders and illnesses), and unequal access to high-level education, it is important to take a closer look at "radical", daring proposals of ensuring welfare, like unconditional basic income [Mulvale 2008] or job guarantees.

These proposals are founded on conceptualisations of welfare contradictory to the "standard" welfare state institutions (Baranowski 2013). Particularly in the case of a basic income guarantee, the need for emancipation of social categories threatened by exclusion (e.g. women, people with lower income or on benefits) is important, but in the context of unconditional support for every citizen (and in some proposals even every denizen). Keeping in mind the above-mentioned antisocial solutions regarding, inter alia, labour market relations, Erik Olin Wright replied to the question "What would society gain from the institution of an unconditional basic income?" as follows: "A generous, unconditional basic income which would allow employees a meaningful exit from a particular employment situation, or indeed from paid employment itself, directly transforms the dynamics of the employer-employee relationship in a private market economy" [2006: 6]. This, in turn, would result in social welfare, because it would broaden the scope of real - though not full - freedom of choice about one's fate. As Wright said: “(...) In a capitalism with basic income people are free to engage in non-marketoriented, socially productive activity. There is a wide range of activities which many people want to do but which are badly organized by either capitalist markets or public institutions" [2006: 6].

Basic income, as a proposal to solve the problem of statutory poverty by means of a cash benefit, goes beyond material needs as narrowly understood. It also entails a (partial) weakening of negative aspects of uncertainty, experienced especially in the context of the labour market and its correlates, as well as culturally impregnated practices of treatment of women, which can have a significant impact on the patterns of political participation. Therefore, the unified view of welfare proposed in this article fits perfectly well within the analysis of the basic income concept. 
Guy Standing used the rules of social justice, in the understanding presented above [see also Standing 2017: 88-89], to assess the concept of a basic income guarantee against known social security solutions. The results of this summary are presented below (Table 2.).

TABLE 2. How different welfare schemes satisfy social justice principles.

\begin{tabular}{|l|c|c|c|c|c|}
\cline { 2 - 6 } \multicolumn{1}{c|}{} & $\begin{array}{c}\text { Security } \\
\text { difference } \\
\text { principle }\end{array}$ & $\begin{array}{c}\text { Paternalism } \\
\text { test principle }\end{array}$ & $\begin{array}{c}\text { Rights- } \\
\text { not-charity } \\
\text { principle }\end{array}$ & $\begin{array}{c}\text { Ecological } \\
\text { constraint } \\
\text { principle }\end{array}$ & $\begin{array}{c}\text { Dignified } \\
\text { work } \\
\text { principle }\end{array}$ \\
\hline minimum wage & $\mathrm{X}$ & $\mathrm{V}$ & $\mathrm{V}$ & - & - \\
\hline Social insurance & $\mathrm{X}$ & $\mathrm{V}$ & $\mathrm{V}$ & - & - \\
\hline Means testing & $\mathrm{X}$ & $\mathrm{X}$ & $\mathrm{X}$ & - & $\mathrm{X}$ \\
\hline Subsidies, vouchers & $\mathrm{X}$ & $\mathrm{X}$ & $\mathrm{X}$ & - & - \\
\hline Job guarantee & $\mathrm{X}$ & $\mathrm{X}$ & $\mathrm{X}$ & - & $\mathrm{X}$ \\
\hline Workfare & $\mathrm{X}$ & $\mathrm{X}$ & $\mathrm{X}$ & - & $\mathrm{X}$ \\
\hline Tax credits & $\mathrm{X}$ & $\mathrm{X}$ & $\mathrm{X}$ & - & $\mathrm{X}$ \\
\hline Negative income tax & $\mathrm{X}$ & $\mathrm{V}$ & $\mathrm{V}$ & - & $\mathrm{X}$ \\
\hline Charity & $\mathrm{X}$ & $\mathrm{X}$ & $\mathrm{X}$ & - & $\mathrm{X}$ \\
\hline Basic income & $\mathrm{V}$ & $\mathrm{V}$ & $\mathrm{V}$ & $\mathrm{V}$ & $\mathrm{V}$ \\
\hline
\end{tabular}

Source: Standing 2017: 99.

This summary is by no means undisputable, because if we look at the job guarantee proposal [cf. Wisman, Reksten 2013] with respect to both the paternalism test and the rights-not-charity principle, the results are entirely different. Philip Harvey [2013: 13], criticised by Standing, stated very clearly that "the right to work is not accompanied by a duty to work in international human rights law" [see also Harvey 2005].

From the sociological perspective, the job guarantee proposal [Fullwiler 2013, Murray 2013, Wray 2013], created by economists, is ultimately designed to grant welfare to those who struggle on the job market. This is meant to secure a decent salary, as well as grant the psychosocial benefits of being around other people, being useful, etc. Studies of group redundancies (and also outplacement programs) provide a range of valuable data on loss of employment, which can only be compared to the death of somebody close or a divorce. It is true, as is claimed by the critics of the job guarantee proposal, that so-called 'bullshit jobs' do not constitute an alternative to more freedom-oriented and emancipatory solutions. But this does not automatically mean that the job guarantee 
proposal itself would not have a positive impact on social welfare, because it does not include such jobs being created. It would be like rejecting the basic income guarantee by saying that the amount it would provide does not solve any problems of those who are excluded or threatened by exclusion (including the ability to engage oneself in "socially useful activities" that Guy Standing [2017] and Ladislau Dowbor [2014] wrote about). Furthermore, the experiences of the Dutch "Jeugdwerk garantiewet" (JWG programme) for young people, and the Argentinian "Plan Jefes y Jefas de Hogar" [Wray 2006] suggest that job guarantee programs are rather successful.

Within the sociological approach to welfare, one should naturally analyse the proposals, even the most progressive ones, which aim at improving the living conditions of members of the society, as well as identify the areas in which such welfare is being limited [e.g. Cichocki 2017]. In regard to the latter question, we need to be aware for example that the increase in unemployment is accompanied by an increase in a range of negative phenomena, like assault, robbery, rape or murder [Raphael, Winter-Ebmer 2001]. Indeed, the very approach to penalisation, which becomes a giant mechanism of exclusion, should not be neglected by researchers addressing the issue of welfare from the sociological perspective [Wacquant 2009]. In one report it was noted that "measures that affect the economic well-being of the community provide more potential leverage over crime than measures that influence the risk of arrest or the severity of the punishments imposed on offenders" [Wan et al. 2012: 17]. The need for studies like this (not only in regard to crime), as well as an innovative approach to the social determinants of the functioning of local communities (for a study on urban communities see Andy Merrifield [2014]) from the perspective of social welfare, should not be questioned. On every level of analysis, one can observe either functional or dysfunctional aspects of social change, and with the right analytical perspective we can name the changes that are happening and those that influence them (aiding the former and hindering the latter). The sociology of welfare should, on one hand, adhere to the idea of public sociology [Burawoy 2005], that is, an engaged discipline devoted to the good of a society as such, and on the other hand not be indifferent to the changes such as those identified, for example, by Andy Merrifield, who wrote about "a new kind of citizenship (...) an urban citizenship of workers without salaried work, of students without careers (the NINJA generation: »No Income, No Jobs and Assets «), of poor and middle-class people without homes, of retirees without pensions" [2014: 9]. 


\section{CONCLUSIONS}

As Norbert Elias pointed out, one of the dangers in sociology is "fragmenting into even more specialist sociologies - from the sociology of the family to the sociology of industrial organizations, from the sociology of knowledge to the sociology of social change, from the sociology of crime to the sociology of art and literature, from the sociology of sport to the sociology of language. Soon there will actually be specialists in all these fields, elaborating their own technical terms, theories and methods which will be inaccessible to non-specialists" [Elias 1978: 50]. Today these fears are certainly not unfounded, although one needs to take a look at the nature of the processes and phenomena in question in order to be able to make a responsible decision regarding the adopted methodological perspective, including an attempt to distinguish a certain sub-discipline. If the research conducted by sociologists [Therborn 2013], economists [Atkinson 2015, Piketty 2017, Stiglitz 2013], epidemiologists [Wilkinson and Picket 2009], and psychologists [Schütte et al. 2014] confirms growing socioeconomic inequalities with their multifaceted consequences, including in developed capitalist economies, then the issue of welfare, which inspires both theoretical and practical endeavours, should be reformulated. This means a re-thinking and re-formulation of overly narrow theoretical formulations because, as Anthony Atkinson [2015: 3] rightly noted - "Inequality is embedded in our social and economic structure, and a significant reduction requires us to examine all aspects of our society." And when we take into consideration the material and psychological determinants in areas such as not only health, employment, and security, but also sexuality, education, etc., the sociological perspective on welfare becomes even more important. This is all the more so because the increase in socioeconomic inequalities and uncertainty with respect to living conditions is accompanied by an increase in radicalisation, which strengthens the feeling of insecurity, in turn legitimizing the development of an apparatus of state violence in the name of the greater good. This in turn further limits civil rights, which only worsens the already tragic situation for the weakest social categories, who experience the antisocial character of the institutions of social policy. Not only do capitalist corporations exert pressure on their employees, but states also abuse "austerity governance" and "rule by accountancy", and in order "to balance municipal and federal books, family treasures have been sold off, public sector assets privatized, service management contracted-out; and land has generally been given away or sold at lowly fire-sale prices" [Merrifield 2014: 25]. Such a "landscape" does not foster pro-social orientation, neither does it benefit the development of public goods and coopera- 
tion [cf. Ferrari 2016], which together could form an opposition to the neoliberal reality which sabotages the welfare of broad social categories, promoting wealth of a small - one could even say hand-picked - part of the society. Unfortunately, the welfare of the few is not without consequences to the situation of the many, particularly those living below the poverty line. That is why we are in serious need of an engaged sociology of welfare, which unmasks practices of exclusion and proposes innovative changes within the existing welfare state institutions and constitutes an important element of active work towards the improvement of living conditions.

\section{REFERENCES}

Atkinson Anthony B. 2015. Inequality. What can be done? Cambridge, MA: Harvard University Press.

Ball Richard, Kateryna Chernova. 2008. "Absolute income, relative income, and happiness". Social Indicators Research 88: 497-529.

Baranowski Mariusz. 2013. "Towards the welfare state sociology”. Kultura i Edukacja 6(99): $135-148$.

Baranowski Mariusz. 2017. Education in times of uncertainty. Uncertainty in education. A critical approach. In: Symbolic violence in socio-educational contexts. A post-colonial critique, Anna Odrowąż-Coates, Sribas Goswami (eds.), 63-72. Warszawa: Wydawnictwo Akademii Pedagogiki Specjalnej.

Barbieri Paolo. 2009. „Flexible employment and inequality in Europe”. European Sociological Review 25(6): 621-628.

Baudrillard Jean. 1998. The consumer society. Myths and structures. London: SAGE Publications.

Bauman Zygmunt. 2011. Community. Seeking safety in an insecure world. Cambridge: Polity Press.

Beck Ulrich. 1992. Risk society. Towards a new modernity. London: SAGE Publications.

Bengtsson Emil. 2015. Flexploitation or flexibilisation? A cross-sectional study of youth wellbeing In a changing labour market. Lund: Lund University. http://lup.lub.lu.se/luur/download func $=$ downloadFile\&recordOId $=7366123 \&$ fileOId $=7366205$ [access 20.08.2017]

Berger Peter L. 1968. Invitation to sociology. A humanistic perspective. New York: Anchor Books.

Blackshaw Tony. 2016. "British sociology, the bourgeois media-sociology hybrid and the problem of social class". Studia Krytyczne 3: 13-43.

Burawoy Michael. 2005. "2004 ASA Presidential address. For public sociology”. American Sociological Review 70(1): 4-28.

Caruana Robert. 2007. "A sociological perspective of consumption morality". Journal of Consumer Behaviour 6: 287-304.

Castel Robert. 2016. "The rise of uncertainties". Critical Horizons 17(2): 160-167.

Cichocki Piotr. 2017. "Cosmopolitanism in the face of populism - contemporary challenges on the path of european identity formation". Society Register 1(1): 67-74. 
Diener Ed, Eunkook Suh. 1997. "Measuring quality of life: economic, social, and subjective indicators". Social Indicators Research 40: 189-216.

Dowbor Ladislau. 2014. Economic democracy. Saarbrücken: LAMBERT Academic Publishing.

Elias Norbert. 1978. What is sociology? Transl. by Stephen Mennell and Grace Morrissey. New York: Columbia University Press.

Ferrari Mariana Z. 2016. "Beyond uncertainties in the sharing economy: opportunities for social capital”. European Journal of Risk Regulation 7(4): 664-674.

Fullwiler Scott T. 2013. The costs and benefits of a job guarantee: estimates from a multicountry econometric model. In: The job guarantee. Toward true full employment, Murray Michael J., Mathew Forstater (eds.), 73-94. New York: Palgrave Macmillan.

Giddens Anthony. 1995. Affluence, poverty and the idea of a post-scarcity society. United Nations Research Institute for Social Development. http://www.unrisd.org/80256B3C005BCCF9/(httpAuxPages)/D04C41AAF1FA94FF80256B67005B67B8/\$file/dp63.pdf [access 20.08.2017].

Gouldner Alvin W. 1968. "The sociologist as partisan: sociology and the welfare state". The American Sociologist 3(2): 103-116.

Graaf John de, David Wann, Thomas H. Naylor. 2005. Affluenza. The all-consuming epidemic. 2nd Edition. San Francisco, CA: Berrett-Koehler Pubishers.

Graham Carol, Andrew Felton. 2005. Does inequality matter to individual welfare? An initial exploration based on happiness survey from Latin America. Washington: The Brookings Institution (revised draft).

Harvey David. 2014. Seventeen contradictions and the end of capitalism. Oxford: Oxford University Press.

Harvey Philip. 2005. "The right to work and basic income guarantees: competing or complementary goals? Rutgers Journal of Law and Public Policy 2(1): 8-59.

Harvey Philip. 2013. "More for less: the job guarantee strategy". Basic Income Studies 7(2): 3-18.

Henriksen Peter. 1987. "Some perspectives on scandinavian welfare research". Acta Sociologica 30(3/4): 379-392.

Kaplow Louis, Steven Shavell. 2001. "Any non-welfarist method of policy assessment violates the pareto principle". Journal of Political Economy 109(2): 281-286.

MacGregor Susanne. 2005. The welfare state and neoliberalism. In: Neoliberalism. A critical reader, Saad-Filho Alfredo, Deborah Johnston (eds.), 142-148. London - Ann Arbor, MI: Pluto Press.

Marshall Thomas H. 2009. Citizenship and social class. In: Inequality and society. Social science perspectives on social stratification, Manza Jeff, Michael Sauder (eds.), 148-154. New York: W. W. Norton and Co.

Max-Neef Manfred. 1995. "Economic growth and quality of life: A threshold hypothesis". Ecological Economics 15: 115-118.

Merrifield Andy. 2014. The new urban question. London: Pluto Press.

Morgen Huset M. 2007. What lies ahead for the Nordic model? A discussion paper on the future of the Nordic welfare model in a global competition economy. Copenhagen: Nordic Council of Ministers. http://www.diva-portal.org/smash/get/diva2:702529/FULLTEXT01. pdf [access 20.08.2017].

Mulvale James P. 2008. "Basic income and the Canadian welfare state: exploring the realms of possibility”. Basic Income Studies 3(1): 1-26. 
Murray Michael J. 2013. Effective demand, technological change, and the job guarantee program. In: The job guarantee. Toward true full employment, Murray Michael J., Mathew Forstater (eds.), 95-124. New York: Palgrave Macmillan.

North Douglass C. 1990. Institutions, institutional change and economic performance. Cambridge: Cambridge Univesrity Press.

Piketty Thomas. 2017. Capital in the twenty-first century. London: The Belknap Press of Harvard University Press.

Raphael Steven, Rudolf Winter-Ebmer. 2001. "Identifying the effect of unemployment on crime". Journal of Law and Economics 44(1): 259-283.

Rawls John. 1999. A Theory of justice. Revised edition. Cambridge, MA: The Belknap Press of Harvard University Press.

Renn Ortwin. 2008. Risk governance. Coping with uncertainty in a complex world. London: Earthscan.

Schütte Stefanie, Jean-François Chastang, Agnès Parent-Thirion, Greet Vermeylen, Isabelle Niedhammer. 2014. "Social inequalities in psychological well-being: A European comparison". Community Mental Health Journal 50(8): 987-990.

Sen Amartya. 2000. Development as freedom. New York: Alfred A. Knopf.

Standing Guy. 2011. The precariat: the new dangerous class. London - New York: Bloomsbury Academic.

Standing Guy. 2014. A precariat charter: From denizens to citizens. London - New York: Bloomsbury Academic.

Standing Guy. 2017. Basic income: and how we can make it happen. London: Pelican.

Stiglitz Joseph E. 2013. The price of inequality. How today's divided society endangers our future. New York: W.W. Norton.

Taylor David. 2011. "Wellbeing and welfare: A psychosocial analysis of being well and doing well enough". Journal of Social Policy 40(4): 777-794.

Therborn Göran. 2013. The killing fields of inequality. Cambridge: Polity Press.

Touraine Alain. 2014. After the crisis. Oxford: Polity Press.

Veenhoven Ruut. 2008. Sociological theories of subjective well-being. In: The Science of subjective well-being, Eid Michael, Randy J. Larsen (eds.), 44-61. New York - London: The Guilford Press.

Wacquant Loïc. 2009. Punishing the poor. The neoliberal government of social insecurity. Durham - London: Duke University Press.

Wallerstein Immanuel. 1999. The end of the world as we know it. Social science for the twentyfirst century. Minneapolis - London: University of Minnesota Press.

Wan Wai-Yin, Steve Moffatt, Craig Jones, Don Weatherburn. 2012. "The effect of arrest and imprisonment on crime". Contemporary Issues in Crime and Justice 158: 1-20.

Wilkinson Richard H., Kate Picket. 2009. The spirit level. Why equality is better for everyone. London: Penguin.

Wisman Jon D., Nicholas Reksten. 2013. Rising job complexity and the need for government guaranteed work and training. In: The job guarantee. Toward true full employment, Murray Michael J., Mathew Forstater (eds.), 5-38. New York: Palgrave Macmillan.

Wray L. Randall. 2006. "Lesson form Argentina's employment guarantee". Economic and Political Weekly 41(23): 2293-2296. 
Wray L. Randall. 2013. The Euro crisis and the job guarantee: A proposal for Ireland. In: The job guarantee. Toward true full employment, Murray Michael J., Mathew Forstater (eds.), 161-177. New York: Palgrave Macmillan.

Wright Erik Olin. 2006. "Two redistributive proposals - universal basic income and stakeholder grants". Focus 24(2): 5-7.

Zinn Jens. 2007. Uncertainty. In: The Blackwell encyclopedia of sociology. R. George (ed.), 5097-5098 Malden, MA: Blackwell Publishing.

Mariusz Baranowski

\section{SOCJOLOGIA DOBROBYTU W NASZYCH CZASACH. JAK SPOŁECZNE, POLITYCZNE I EKONOMICZNE NIEPEWNOŚCI KSZTAŁTUJĄ WSPÓLCZESNE SPOŁECZEŃSTWA}

Streszczenie

Niniejszy artykuł próbuje przybliżyć podejście socjologii dobrobytu do problemów i dylematów współczesnych, rozwiniętych społeczeństw kapitalistycznych. Oprócz charakterystyki obszarów zainteresowania socjologii dobrobytu, szczególnie w kontekście ekonomii dobrobytu i psychologii pozytywnej, nacisk zostanie położony na opis kondycji współczesnych społeczeństw. W tym celu użyty zostanie termin „niepewność”, który dobrze nadaje się do charakterystyki różnych wymiarów ponowoczesnych społeczeństw. Należy jednak pamiętać, że koncepcja socjologii dobrobytu nie stanowi (z wyjątkiem prac ekonomistów nad prekarnymi formami zatrudnienia) wyartykułowanego punktu widzenia. W ujęciu socjologicznym kategoria dobrobytu posłuży do analizy zmian w strukturze zróżnicowania społecznego, jak również w relacjach społecznych, możliwościach edukacyjnych, postawach politycznych, wzorcach konsumpcji i wypoczynku, by wymienić tylko kilka. Wszystkie te zmiany odzwierciedlają nie tylko wpływ globalizacji na systemy zabezpieczenia społecznego, ale także konsekwencje rewolucji technologicznej i wyzwań demograficznych na subiektywnie postrzegany dobrobyt społeczny.

Słowa kluczowe: socjologia dobrobytu, niepewność, sprawiedliwość społeczna, prekariat, antyspołeczne zmiany instytucjonalne 